\title{
New Colorimetric Method for Lipases Activity Assay in Microbial Media
}

\author{
Mohamed A. Abd-Elhakeem ${ }^{1}$, Ahmed M. Elsayed ${ }^{2}$, Taher A. Alkhulaqi ${ }^{1}$ \\ ${ }^{1}$ College of Biotechnology, Misr University for Science and Technology, Giza, Egypt \\ ${ }^{2}$ Research and Development Center, Misr University for Science and Technology, Giza, Egypt \\ Email: Mohamed.abdelhakim@must.edu.eg
}

Received June 2, 2013; revised July 2, 2013; accepted August 10, 2013

Copyright (C) 2013 Mohamed A. Abd-Elhakeem et al. This is an open access article distributed under the Creative Commons Attribution License, which permits unrestricted use, distribution, and reproduction in any medium, provided the original work is properly cited.

\begin{abstract}
A simple, rapid and precise method has been developed for determination of lipase activity in microbial media. The method is based on using phenyl acetate as substrate for lipase and determination of liberated phenol by Folin Ciocalteu reagent. Reaction mixture containing substrate $2.4 \mathrm{ml}$ of phenyl acetate $165 \mu \mathrm{M}$ in Tris $\mathrm{HCl}$ buffer, $0.1 \mathrm{M}$ and $\mathrm{pH} 7$, with $1 \%(\mathrm{v} / \mathrm{v})$ Triton $\mathrm{X}-100)$ and $0.1 \mathrm{ml}$ lipase is incubated at $40^{\circ} \mathrm{C}$ during 10 minutes and the absorbance was measured at $750 \mathrm{~nm}$. Linearity was observed in the concentration range $0-0.8 \mathrm{~g} / \mathrm{L}$ lipase.
\end{abstract}

Keywords: Lipase; Colorimetric Method; Assay; Phenyl Acetate; Folin

\section{Introduction}

Lipases (triacylglycerol acylhydrolases, E.C. 3.1.1.3) are one of the most important classes in biotechnology that can catalyze the hydrolysis of ester bond at the lipid and water interface [1]. Among different sources of the lipases, only microbial lipases have high interest due to their commercially significance [2]. During the lipase production, it is important to determine the lipase activity by a simple and rapid method to select the best condition for the production. Although several methods have been developed for the determination of lipase activity, only two methods are commonly used in the literatures.

The first one is the titrimetric method using olive oil as substrate. This method depends on the determination of the liberated fatty acids by titration against potassium hydroxide [3]. The second method is the colorimetric method using p-nitrophenyl palimitate as a substrate and determines the lipase activity by measuring the amount of the yellow chromogen (p-nitrophenol) resulting from the hydrolysis of the substrate [4].

Generally the colorimetric methods are more favorable due to their simplicity, rapidness and only small volume of the sample is needed for analysis. But the chemicals of the colorimetric method are very expensive. Beside the high cost of the current colorimetric method, there are many technical disadvantages starting with the dissolving of the substrate, where many additives have been used to make a homogeneous solution such as tween [5], sodium deoxycholate [6], sodium dodecyl Sulphate [7], Arabic gum [8] and finally Triton X-100 [9]. The main disadvantage of the current method is the releasing of palmitic acid that is insoluble in water that causes turbidity in the measurement test tube that alters the spectrophotometric reading. Some literatures partially solve this problem by the addition of calcium chloride $\left(\mathrm{CaCl}_{2}\right)$ to the reaction mixture to remove the fatty acids as calcium salts by centrifugation. Also many research papers that apply the current colorimetric method don't include a step of enzyme deactivation step, this leads to continual enzymatic action on the substrate leading to an overestimation of the enzyme titer values [9]. Finally, this method is not suitable for colored media.

In the current work, we investigated a new method to determine the lipase activity starting with phenyl acetate that is low price commercially available. The phenyl acetate ester bond is hydrolyzed by the lipase to release phenol and acetic acid that are soluble in water and so there is no turbidity formed. The liberated phenol can be detected by adding the Folin reagent that forms a clear blue color with phenol and it is able to detect very small traces of phenol. The concentration of the phenol is directly in proportion with the lipase activity. 


\section{Experimental}

\subsection{Materials}

Lipase enzyme from Candida antarctica B, Phenyl acetate, phenol, sodium carbonate, Triton X-100 and Folin Ciocalteu reagent were purchased from Sigma Aldrich

\subsection{Preparation of Substrate Solution}

A weight of phenyl acetate was dissolved in buffer soluti on containing $1 \%$ Triton X-100 to make the final concentration $200 \mu \mathrm{M}$. each analysis was made by freshly prepared solution.

\subsection{Method Optimization}

For the optimization of the method, several parameters were tested, buffer type, $\mathrm{pH}$, reaction time, and substrate concentration. The parameters optimization was performed step by step, always considering the modifications adopted in the previous step.

The primary test was done based on conventional colorimetric assay of lipases described in the literatures which is $\mathrm{pH} 7,40^{\circ} \mathrm{C}$ and incubation for 15 minutes using $2.4 \mathrm{ml}$ of $200 \mathrm{mM}$ substrate with $0.1 \mathrm{ml}$ of $0.4 \mathrm{~g} \cdot \mathrm{L}^{-1}$ lipase solution. Three different $\mathrm{pH} 7$ buffers were tested in aqueous lipase solution, sodium phosphate $0.05 \mathrm{M}$, Tris$\mathrm{HCl} 0.1 \mathrm{M}$ and sodium acetate $0.05 \mathrm{M}$.

In order to investigate the effect of $\mathrm{pH}$ in the lipolytic assay, the selected buffer from the first step was tested at different $\mathrm{pH}$ values of 5,6,7, and 8 . The time-dependent activity variation was monitored under the optimized assay conditions. Five test tubes were prepared in the same manner and incubated. One test tube was taken to determine the absorbance every 10 minutes.

\subsection{Effect of Substrate Concentration}

Different substrate tubes of concentration range from zero up to $200 \mu \mathrm{M}$ were prepared by dissolving of 113.3 mg of phenyl acetate in $10 \mathrm{ml}$ Tris $\mathrm{HCl}$ buffer $\mathrm{pH} 7$, then $0,0.5,1,1.5,2,2.4 \mathrm{ml}$ was taken from the solution and completed up to $2.4 \mathrm{ml}$ by distilled water, finally $0.1 \mathrm{ml}$ of lipase enzyme was added and the enzyme activity was measured at the optimized conditions.

\subsection{Method Linearity}

Five independent assays at different enzyme concentrations (comprised in a range from $0 \mathrm{~g} \cdot \mathrm{L}^{-1}$ to $2 \mathrm{~g} \cdot \mathrm{L}^{-1}$ ) were prepared and analyzed to check the linearity of response.

\subsection{Precision}

Repeatability of the sample preparation and measurement were carried out by measuring five replicates of samples of concentration in the linear range. The results were expressed in terms of percent relative standard deviation (\% RSD).

\section{Results and Discussion}

By using the primary conditions Tris- $\mathrm{HCl}$, buffer showed the highest lipolytic activity so it was decided to precede the optimization with that buffer. Testing the lipolytic activity using Tris- $\mathrm{HCl}$ and the same primary conditions with different $\mathrm{pH}$ range indicate that $\mathrm{pH} 6$ and $\mathrm{pH} 7$ are the most suitable $\mathrm{pH}$ for lipase assay by our method with slightly difference. Finally studying the incubation time indicates that the best incubation time was 10 minutes. All results are summarized in Table $\mathbf{1}$.

\subsection{Effect of Substrate Concentration}

Vmax is theoretically defined as the maximum initial rate of an enzyme catalyzed reaction, i.e., when virtually all the enzyme present in the reaction mixture is present as enzyme-substrate complex.

Practically Vmax is the maximum activity that can be obtained by a constant amount of enzyme. $\mathrm{Km}$ is the concentration of substrate which permits the enzyme to achieve half Vmax.

Vmax and $\mathrm{Km}$ can be determined by plotting a relation between $1 /$ substrate concentration and 1/enzyme activity.

$$
\begin{aligned}
& \mathrm{Vmax}=1 / \mathrm{Y} \text { intercept } \\
& \mathrm{Km}=-1 / x \text { intercept }
\end{aligned}
$$

Figure 1 illustrates that the best activity of lipase $(0.26$ $\mathrm{U} / \mathrm{ml}$ ) was obtained at substrate concentration of 165 $\mu \mathrm{M}$.

\subsection{Linearity}

Linearity of an analytical procedure is its ability (within a

Table 1. Show different conditions of the new method of lipase assay. The best conditions were using Tris-HCl buffer, pH 7 and incubation for $10 \mathrm{~min}$.

\begin{tabular}{cccccc}
\hline Buffer & $\begin{array}{c}\text { Lipase } \\
\text { activity } \\
\text { U/ml }\end{array}$ & $\mathbf{p H}$ & $\begin{array}{c}\text { Lipase } \\
\text { activity } \\
\text { U/ml }\end{array}$ & $\begin{array}{c}\text { Time } \\
\text { (Min.) }\end{array}$ & $\begin{array}{c}\text { Lipase } \\
\text { activity } \\
\text { U/ml }\end{array}$ \\
\hline & & 5 & 0.07 & & \\
Tris-HCl & $\mathbf{0 . 1 6}$ & & 0.14 & & \\
& & 7 & $\mathbf{0 . 1 7}$ & 30 & 0.16 \\
& & & & 40 & 0.10 \\
& & & & 50 & 0.07 \\
Phosphate & 0.09 & & 0.09 & & \\
Acetate & 0.11 & & & & \\
\hline
\end{tabular}




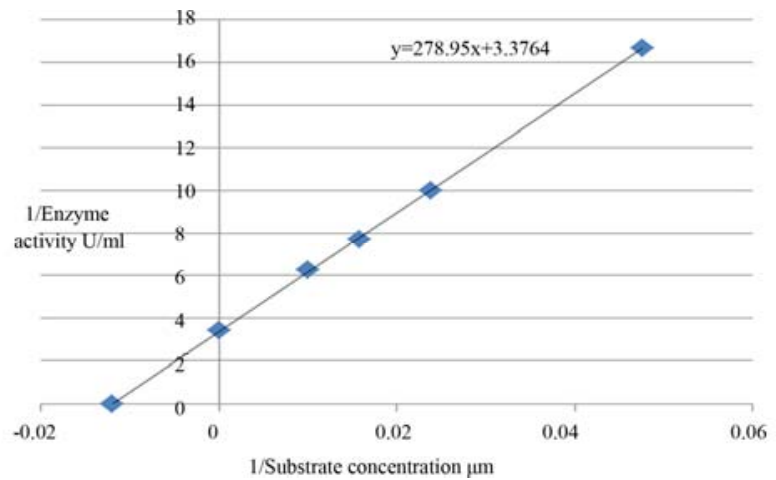

Figure 1. Relation between $1 /$ substrate concentration and 1 /enzyme activity to calculate Vmax and $\mathrm{Km}$.

given range) to obtain test results that are directly proportional to the concentration of analyte in the sample. It was defined through the relation between lipase concentration and absorbance measured at $750 \mathrm{~nm}$. According to this statistical methodology, the calibration curve obtained from the relation between lipase concentration and the corresponding absorbance values determined at 750 $\mathrm{nm}$ was linear for the concentration ranges of 0 to 0.8 $\mathrm{g} \cdot \mathrm{L}^{-1}$.

\subsection{Precision}

Standard deviation showed how much variation exists from the average (mean). A low standard deviation indicated that the data points tend to be very close to the mean or in other word precise. 5 repeated reading of enzyme solutions were made for three consecutive days and the \%RSD were calculated. From the data obtained, the method was found to be precise with \%RSD equal 2.25 .

\section{Conclusions}

A new method for determination of lipase activity based on the determination of phenol that released from hydrolysis of phenyl acetate was investigated. The new method is suitably optimized and partially validated

During our work, we noted that the phenyl acetate is gradually dissociated when dissolved in the buffer solution and so only freshly prepared phenyl acetate can be used within one hour of preparation. Also, we recommend the investigation of other commercially available phenolic esters, such as acetyl salicylate or naphthyl acetate.

\section{REFERENCES}

[1] R. Sharma, Y. Chisti and U. C. Banerjee, "Production, Purification, Characterization, and Applications of Lipases," Biotechnology Advances, Vol. 19, No. 8, 2001, pp. 627-662. doi:10.1016/S0734-9750(01)00086-6

[2] K. R. Shah and S. A. J. Bhatt, "Purification and Characterization of Lipase from Bacillus subtilis Pa2," Journal of Biochemical Technology, Vol. 3, No. 3, 2011, pp. 292-295.

[3] F. Beisson, A. Tiss, C. Rivi_ere and R. Verger, "Methods for Lipase Detection and Assay: a Critical Review," Eur. European Journal of Lipid Science and Technology, Vol. 102, No. 2, 2000, pp. 133-115. doi:10.1002/(SICI)1438-9312(200002)102:2<133::AID-E JLT133>3.3.CO;2-O

[4] F. Hasan, A. A. Shah and A. Hameed, "Methods for Detection and Characterization of Lipases: A Comprehensive Review," Biotechnology Advances, Vol. 27, No. 6, 2009, pp. 782-798. doi:10.1016/j.biotechadv.2009.06.001

[5] A. A. Amara and S. R. Salem, "Degradation of Castor Oil and Lipase Production by Pseudomonas aeruginosa," American-Eurasian Journal of Agricultural \& Environmental Sciences, Vol. 5, No. 4, 2009, pp. 556-563.

[6] D.-S. Park, H.-W. Oh, S.-Y. Heo, W.-J. Jeong, D. H. Shin, K. S. Bae and H.-Y. Park, "Characterization of an Extracellular Lipase in Burkholderiasp. HY-10 Isolated from a Longicorn Beetle," The Journal of Microbiology, Vol. 45, No. 5, 2007, pp. 409-417.

[7] D. R. Lewis, D. Zhou and J. Liu, "Direct Measurement of Lipase Inhibition by Orlistat Using a Dissolution Linked In Vitro Assay," International Journal of Clinical Pharmacology and Biopharmacy, Vol. 1, No. 3, 2012, pp. 1-3.

[8] Shao-Hua Chiou, Wen-Teng Wu. "Immobilization of Candida rugosa Lipase on Chitosan with Activation of the Hydroxyl Groups," Biomaterials, Vol. 25, No. 2, 2004, pp. 197-204. doi:10.1016/S0142-9612(03)00482-4

[9] N. Gomes, C. Goncalves, M. Garcia-Roman, J. A. Teixeiraa and I. Belo. "Optimization of a Colorimetric Assay for Yeast Lipase Activity in Complex Systems," Analytical Methods, Vol. 3, No. 4, 2011, pp. 1008-1013. doi:10.1039/c0ay00680g

[10] N. Gupta, P. Rathi and R. Gupta. "Simplified Para-Nitrophenyl Palmitate Assay for Lipases and Esterases," Analytical Biochemistry, Vol. 311, No. 1, 2002, pp. 98-99. doi:10.1016/S0003-2697(02)00379-2 